\title{
DO FINANCIAL STATEMENTS PROVIDE ADEQUATE INFORMATION ABOUT THE CAPITALIZATION OF COSTS RELATED TO INTANGIBLEASSETS?: AN EMPIRICAL RESEARCH ON ITALIAN LISTED COMPANIES
}

\author{
Stefania Vignini \\ Researcher, University of Bologna \\ stefania.vignini2@unibo.it \\ Article info \\ Paper category: Review \\ Received: 23.6.2015. \\ Accepted: 27.10.2015. \\ JEL classification: $\mathrm{M}_{41}, \mathrm{O}_{1}, \mathrm{P}_{45}, \mathrm{~N}_{5}$
}




\section{ABSTRACT}

The aim of our research is to verify if Italian listed companies financial statements provide adequate information about the capitalization of costs related to intangible assets and if the information provided are reliable.Moreover, we investigated if they merely comply with law or provide additional information on cost capitalization and reveal if internal control systems (especially managerial accounting systems) or other information systems are applied to support the measurement process and the cost control, thus guaranteeing the verifiability and representational faithfulness of the information disclosed. This paper is an empirical analysis and is concerned to investigate the financial statements of 250 Italian listed companies.

\section{Keywords:}

Managerial accounting systems, Intangibles, Capitalization, Measurement, IAS/IFRS 


\section{INTRODUCTION}

The crisis of the listed companies is partially related to the poor information supplied within financial statements. Catturi (2001) says that the opportunity available by IFRSs/IASs requires communication and information ${ }^{1}$ tools, that must have, in the former, the capacity to transmit a potential readable message by all stakeholders. The situation is also worst if we consider that International ratings agency sometimes provide rating without a deep and/or correct analysis of the financial and economic situation of the companies ${ }^{2}$.

It is appropriate the work of André, Cazavan-Jeny, Dick, (2009) on the link between the fair value accounting and the Banking Crisis in 2008. Their paper sets out to analyze the effects of the financial crisis on the international standard-setter in 2008 and the attempts made to shoot messenger to blame IAS 39 for creating the crisis for reporting unrealised losses, rather than the cause being bankers making had investment decisions. The main part of their paper is a chronological presentation of the events of 2008 as they impact upon the international standard-setting institution. In particular, the Autors analyse the impact of the $\mathrm{G}_{2} \mathrm{O}$ requirements and the blunt intervention of the European Commission that led lo amendments to IAS 39. The final part of the paper looks at the consequences as they are so far discernible and the damage done to the IASB by shooting the messenger.

On the other hand Barth \& Landsman claim, regardless of any role that fair value accounting played in the Financial Crisis: "it is the responsibility of bank regulators, not accounting standard setters, to determine how best to mitigate the effects of procyclicality on the stability of the banking system. To meet their objectives of prudential supervision, bank regulators have many tools at their disposal, including application of prudential filters (as illustrated by the filter for fair value losses on availablefor-sale assets), relaxation of regulatory capital ratios during economic downturns, e.g., by altering risk-weighting of specific assets, and use of counter-cyclical measures in loan provisioning for regulatory purposes" (Barth, Landsman, 2010) ${ }^{3}$.

1 See, among others:K. Chalmers, G. Clinch, J.M. Godfrey, Intangible assets IFRS and analysts' earning forecasts, in Accounting \& Finance, 2012.

2 Among the others you can read: Baldarelli M.G., The globalization Phenomenon and the Pressure for Accounting Harmonization, in Baldarelli M.G., Demartini P., L. Mosnja-Skare, 2007, International Accounting Standards fro SMEs: Empirical evidences from SMEs in a Country in transition and a Developed Country Facing New Challenges, Department of Economics and Tourism "DR. MIJO Mirkovic'; Vignini S., "The enterprise's financial stability in times of crisis", AMS ACTA Bologna (2012), doi: 10.6092/unibo/ amsacta $/ 345^{2}$.

3 Barth \& Landsman conclude: "Finally we conclude that because the objectives of bank regulation differ from the objective of financial reporting, changes in financial reporting requirements to improve transparency of information provided to the capital markets likely will not be identical to the changes in bank regulations needed to strengthen the stability of the banking sector. Moreover, bank regulators have the power to require whatever information is needed to meet the objective of prudential supervision. We conclude that it makes sense from the standpoint of efficiency for accounting standard 
That being said we point out that budgets and business plans, to be reliable, should be checked with both financial accounting and managerial accounting systems, otherwise the quality of information supplied could be non sufficient and misleading. It is appropriate to say that the international accounting principles which follow Anglo-American accounting standards, among which are those issued by the IASC, are influenced by two elements which make them substantially different from traditional Italian accounting techniques and from the very characteristics of our economic system: the first one regards the fact that they are based on patrimonial accounting systems ${ }^{4}$, which have, by now, been surpassed in Italy for many decades; the second one reflects the range of the subjects involved: such international principles are concerned almost exclusively with large-sized enterprises, which resort to the stock markets for their financing, whereas our economic system is dominated by small to medium-sized companies, with capital ownership which is concentrated in the hands of the reference partners. Having said this, there is no doubt that such principles represent a very important breaking-point in the history of national economic and business doctrine.

\section{INTANGIBLE ASSETS: IAS AND IFRS}

Adopting the international accounting principles leads to a budgetary model which is significantly different from that used up to now by national companies, both under the profile of information aims and the consequent conceptual layout, as well as with regards to drafting models and evaluation criteria of the single balance items. There is no doubt that the conceptual layout of the IFRS financial statement of accounts is very far away from that one which developed in Italy following the adoption of IV EEC Directive ${ }^{5}$. The financial-year statement of accounts, drafted following civil law parameters, seems to favour, at historical values, both a configuration of in-

setters and bank regulators to find some common ground. However, it is the responsibility of bank regulators, not accounting standard setters, to determine how best to ensure the stability of the financial system". It is also important: Barth M.E., Landsman W.R., Lang M.H., 2007.

4. For a close examination of the various accounting systems, please see, among other authors: Capodaglio G., Semprini L., Vignini S., (2011), I sistemi contabili, in Capodaglio G. (a cura di), Principi contabili e di bilancio, RIREA, Rome:17-61. In particular, as for a quick examination of the patrimonial system, cf.: Vignini S., Semprini L., Il sistema contabile patrimoniale nelle sue diverse evoluzioni, in Rivista Italiana di Ragioneria e di Economia Aziendale, 2010:644-655. We advise reading, among other authors: Sellhorn T., Gornik-Tomaszewski S., Implications of the IAS Regulation for Research into the International Differences in Accounting Systems, in European Accounting Review, vol.15, supplement 3, 2006:187-217; Schipper, K., The introduction of International Accounting Standards in Europe: implications for international convergence, European Accounting Review, 14 (1), 2005: 101-126.

5 This directive substantially attributes the qualification of aim of the statement of accounts to the principle of clarity and true and appropriate representation of the patrimonial, economic and financial situation of the enterprise. Such provision assumes the role of "general clause", meaning that the principles for the drafting of the statement of accounts and the criteria for evaluating its accounting items derive from it. 
come produced and a notion of net capital which, de facto, privilege the informative expectations of the external financial backers.

In order to prepare financial statements, IAS-IFRS standards require a vast range of prospective data and information that must be subject to verification in the following financial years in order to monitor the reliability of the assessments and estimates made ex ante. Often to render this information implies an intense cooperation between the financial accounting and managerial accounting systems. As an example, IAS 36 provides rules for impairment test related to the assessment of the recoverable amount of goodwill arising from business combinations, as well as of other non-current tangible and intangible assets, particularly in relation to indefinite life intangible assets. To be tested for impairment, goodwill and indefinite life intangible assets arising from a business combination must be allocated to a so called "cash generating unit" of the acquiring entity, which is composed essentially by non-current tangible assets and intangible assets that generate cash inflows that are relatively independent from other assets or group of assets ${ }^{6}$.

As far as tangible assets and intangible assets other than goodwill are concerned, a first relevant issue is represented by the identification of the elements that may be tested individually for impairment, because they generate independent cash inflows, in order for them to be separated from the other non-current assets that shall be grouped in CGUs. The managerial accounting system might assist accountants at this stage, and later on provide useful information about the allocation of goodwill and indefinite life intangible assets arising from business combinations to the acquiring entity's existing CGUs. ${ }^{8}$.

6 The carrying amount of a CGU which has been allocated with goodwill and indefinite life intangible assets must be compared every year with its recoverable amount, it being represented by the higher of its value in use and its fair value less cost to sell. "If it is not possible to determine the recoverable amount (fair value less costs of disposal and value in use) for the individual asset, then determine recoverable amount for the asset's cash-generating unit (CGU). [IAS 36.66] The CGU is the smallest identifiable group of assets that generates cash inflows that are largely independent of the cash inflows from other assets or groups of assets". [IAS 36.6]

7 At this stage it is particularly important to observe how the accounting items which make up the operations acquired (from which goodwill and intangible assets arise due to the allocation of the acquisition cost) are integrated in the acquirer's operations, in order to verify if, for impairment purposes, the acquired operations either maintain an accounting identity, for example as an independent CGU, or is dismembered, its items being allocated to the existing CGUs of the acquirer according to the methods recommended by IAS 36. Actually, IAS 36 requires to determine the size and shape of CGUs which have been allocated with goodwill and other indefinite life intangible assets between a minimum size, represented by the lowest level within the entity at which goodwill and intangible assets are monitored for internal management purposes, and a maximum size, which must not be greater than an operating segment as defined by paragraph 5 of IFRS 8 before aggregation. The determination of the size of each CGU is a very relevant issue, because IAS 36 requires the composition of CGU to be changed if and only if either a disposal of part of a CGU or a combination between two or more CGUs occurs, or as a consequence of the reorganization of the entity's reporting structure which results in more useful information as for goodwill impairment test purposes

8 In this perspective, a good managerial accounting control system can guarantee: the correct correlation between the carrying values of the items allocated to any individual CGU and cash inflows generated by that specific CGU, in order to prevent from comparing heterogeneous data (i.e. the carrying 
It is apparent that a strong interaction between the information provided about the recoverability of the accounting value of CGUs and the managerial control system implemented by the entity, whereas it helps the ex-post verification of the results of forecasts made in previous financial statements, represents the basis for a continuous improvement of the entity's planning system and strengthens the confidence of users upon the degree of reliability of information disclosed in the entity's financial statement?.

Finally it has to he observed that many IAS-IFRS require information or calculations derived from the entity's managerial accounting system to be used for measurement purposes (Warren, Reeve, Duchac, 2013), in preparing IFRS-compliant financial statements ${ }^{10}$.

In general intangible investments have become the main value creators for many companies and economic sectors. However, these investments are rarely recognized as assets by current accounting standards. In particular, measurement process (Petty, Guthrie, 2000; Guthrie, Petty, Johanson, 2001; Eckstein, 2004) should be supported by an adequate and consistent information structure. If this is not

amount of CGU "A" is compared to values of cash inflows and/or net realizable value reciprocally over or underestimated in relation to the assets which make up the CGU); the control of the reliability of the forecast process used by the entity for impairment test purposes by means of a variance analysis between consumptive data and forecasts used in previous years' financial statements; the basis used for the allocation of goodwill arisen in business combinations to every CGU to which it is apportioned for impairment test purposes and the rationale underlying the choice; the consistency between the timing horizon of future cash flows forecast used for impairment test purposes and reasonable and supportable assumptions based upon a reliable managerial accounting system; the choice of discount rates consistent with those used by the entity in case of investment analysis; the correct allocation among the entity's CGUs of any common disposal cost in order to determine the fair value less cost to sell for each CGU.

9 In fact there are a lot of indications arising from internal reporting:

1) cash flows for acquiring the asset, or availability. It will make subsequent cash needs for operating or preserve the activity, significantly higher than those budgeted;

2) actual net cash flows or operating profit or loss following the exercise of which are revealed significantly worse than those budgeted;

3 ) a significant decline in net cash flows or income Operating budgeted, or a significant increase in the loss budgeted, resulting from the asset;

4) operating losses or net cash outflows activity, when the amounts of the current period are aggregated with budgeted amounts for the future.

10 For example:

- elements of cost to be measured at initial recognition of non-current tangible assets ( IAS 16 . $§ \S_{16}$ and ${ }_{17}$ ), investment properties (IAS $40, \S_{20-21}$ ), or assets held under a finance lease contract ( IAS $17.24)$;

- elements of subsequent costs related to non-current tangible assets to be compared with the increase in inflows of future economic benefits related to the expenditure of those subsequent costs in order to make judgments about their capitalization (IAS 16, §12-13);

- component approach for amortization of non-current tangible assets which can be divided into elements, the useful lives of which are different (16.43);

- methods to be used for the determination of fair value of investment property and in order to avoid double-counting costs related to separate assets and liabilities ( $\operatorname{IAS}_{4}, 0, \S_{5} \mathrm{O}$ );

- criteria used for the capitalization of borrowing costs in the value of a qualifying asset, with particular reference to the cost incurred for general financing activity ( $\left.\operatorname{IAS}_{2} 3,13-14\right)$ ). 
available, it is impossible to adopt measurement criteria that could be considered scientifically and technically correct, so that it is impossible to justify them towards subjects who are to express judgments about them.

This issue is particularly up to date in Italy, since listed companies are required to adopt IAS-IFRS for their financial statements: those standards require the adoption of evaluation criteria that are often strictly related to the implementation of the strategies and the management of the companies. As a consequence, it is more and more important to verify if managerial accounting systems are good enough to find useful information in order to evaluate assets and liabilities within financial statements, since historical cost is less and less adopted, living space to fair value measurements that are generally based on future estimates and projections.

\section{INTANGIBLE ASSETS: A LITERATURE REVIEW}

In this section we want to bring the not simple debate on classification of intangible assets and on their disclosure within the information system.

Amir and Lev (1996) argue that while intangible assets contribute to the market value of the firms, current accounting rules do not allow recording these assets. Consequently information provided in financial statements is not useful to investor when valuing the firms with large amounts of intangible assets. This is observable in general, regardless of the companies that even have a very significant presence of these values, because they belong to particular sectors (Accounting Information for Intangible-Intensive).

In order to classify something one has to have a purpose of the classification. Very useful work arrangement of the literature offered by Artsberg \& Mehtiyeva (2010). Classification criteria can never be true or false, only more or less useful according to the suggested purpose of the classification (Rosing, 1978). In accounting, items have been classified for a number of reasons. The purpose of the categorization into current and non-current assets has been to help users to calculate measures like liquidity and solvency. Another purpose for classification in accounting has been to discuss measurement solutions since different measures are used for different categories of assets, i.e. historical cost used for non-current assets, fair value for financial items and so on.

Walker (2009) concludes that it is difficult to find any stated purpose for classification in many papers that do classify intangibles. However, one purpose seems to be for management purpose. In order to manage successfully one has to make visible and put labels on different resources; one way to do that is to put them into different categories (Kaufman, Schneider, 2004). 
But even so, there are many proposals for intangible assets classification. Lev (2001) writing in the tradition of intellectual capital classifies intangibles into four groups:

- Discovery/learning; ex R\&D

- Customer-related; ex brands, trademarks, distribution channels

- Human-resource; ex. Education, training and compensation systems

- Organization capital; structural organization design, business processes, unique corporate culture

One fashion concept much used and discussed is the concept of intellectual capital'. Some authors (Lev 2001, for example) do use this concept as synonymous with 'intangibles'. In a literature review conducted by Kaufmann \& Schneider (2004) it was concluded that there is no well-established generally accepted definition or classification of intellectual capital. The pioneering work by Edvinson \& Malone (1997) which classified into two categories: human capital and structural capital has strongly influenced other researchers. However, it seems like most researchers in this tradition now classify into three categories; one related to employees that is most often called human capital, a second related to internal processes and structures most often called structural capital or organizational capital, a third related to customers called external structure, relational capital or customer capital (Kaufmann, Schneider, 2004). However, as Kaufmann and Schneider (2004) concludes the literature in this line of research has generally not specified a clear purpose for writing about and classifying intangibles. They found the categorization to be very abstract and the categories quite broad.

Moreover Blair and Wallmann (2000) - directors of the Brooking's institution research project on intangible assets- distinguished three major categories of intangibles:

(1) Intangibles for which property rights are relatively clear and for which markets exist (generally can be bought and sold). Within this category, two types of intangibles can be distinguished:

(2) Assets such as patents, copyrights and trade names;

(3) Business agreements, licenses, enforceable contracts, and data bases.

(4) Intangibles that are controlled by the firm but for which well-defined and legally-protected property rights may not exist, and markets are weak or nonexistent. Examples are R\&D in process, business secrets, reputational capital, proprietary management systems, and business processes.

(5) Intangibles for which the firm has few, if any, control rights and markets do not exist, and which are tied to the people who work for the firm. Examples are human assets, structural (or organizational) assets, and relational assets, i.e. the components of intellectual capital. 
According to Ashton (2005), the guiding principle for Blair and Wallman's (2000) classification scheme is related to the degree of difficulty of establishing ownership or control rights and more generally the difficulty of measurement. In this sense, the third category of intangibles raises more accounting problems than the second category and far more than the first category.

Finally other classifications, mainly developed by accounting standard-setters, were limited to two categories of intangible assets: internally generated intangibles and externally acquired ones. In this setting, externally acquired intangibles do not generally raise accounting problems as the price of these assets has been generally determined during the transaction in monetary form. Inversely, serious accounting problems could arise when the asset is internally generated by the company.

As regards the works on the disclosure ${ }^{11}$, it is very important the study of Gelb (2002) that shows an empirical investigation on Intangible Assets.

Then provocative is the work of Penman where he concludes: "Accounting is often criticized for omitting intangible assets from the balance sheet. This paper points out that the omission is not necessarily a deficiency. There is also an income statement, and the value of intangible (and other) assets can be ascertained from the income statement. Thus, calls for the recognition of 'intangible assets' on the balance sheet may be misconceived. His paper lays out the properly whereby the income statement corrects for deficiencies in the balance sheet. Many commentators view the omission of intangible assets' from balance sheets as a glaring deficiency" ${ }^{\prime 2}$. The main point of the paper simply reminds us that accounting reports not only a balance sheet but also an income statement.

Amir and Lev (1996) find that earnings and book values for firms with significant levels of intangible assets tend to be excessively understated relative to their market values. They argue that because of the inadequacies inherent in traditional accounting reports, firms with significant intangible assets often utilize non accounting information to supplement their accounting disclosures.

11 In reference to the disclosure we want to remember, among the others: Bozzolan S., Favotto F., Ricceri F, Italian annula intellectual capital disclosure. An empirical analysis, in Journal of Intellectual Capital, (2003: 543-558); Botosan C.A., Disclosure and the cost of capital: what do we know?, in Accounting and Business Research, (2006: 31-4,0); Ling-Ching L.A.,Chan Jia-Lang Seng, Intellectual capital disclosure and accounting standards, in Industrial Management \& Data Systems, vol.113, (2013: 1189-1205).

They (many commentators) ask:" How can accountants report a balance sheet that omits important assets like brands, distribution and supply chains, knowledge, human capital, and organization capital, particularly when value in modern firms comes more from these assets than from the tangible assets on the balance sheet? The complaint reached a crescendo during the 1990 s as technology and internet firms identified with these types of 'assets' came to the market with high price-to-book ratios. While diminuendo followed as the perceived intangible assets for many of these firms seemingly evaporated, the accounting for intangible assets continues as a significant research area. Indeed, the current trend towards booking more value to the balance sheet with fair value accounting involves many of the same issues. This paper provides a perspective that I hope is not only helpful to researchers grappling with accounting issues, but also to analysts who use financial statements to value firms with so-called intangible assets". 
Other ways to argue for not capitalizing intangibles is that disclosure is a better way to inform about intangibles. The debate then will be about whether or not such information will be disclosed voluntarily as a result of market incentives or if there is a need to make it mandatory by regulation. Skinner (2008) does not believe in mandatory rules because he claims that measures must be different in different industries (or even companies) and therefore difficult to standardize. If standards are written they must be on a high level of generality to cover the wide variation necessary and because of that we will have implementation problem with a risk that preparers circumscribe the standards and make vague, uninformative disclosures (Skinner 2008). At least in the U.S.A. there is evidence that when the FASB issues standards that are flexible enough to give the companies discretion there is a significant level of non-compliance (Marquardt, Wiédman, 2008).

Skinner (2008) believes that companies will oppose standardization because of proprietary costs. However, he claims that companies, if they find information relevant, will voluntarily disclose it.

Dedman et al seem first to agree with Skinners (2008) conclusion, with evidence from the USA, that there is weak evidence for the need to regulate disclosure of additional information on intangibles but, with the example of two scandal cases in the biotechnical sector in the UK, they claim that market incentives may not only have positive effects but adverse effects tempting some companies to make overly favorable disclosures or fail to disclose bad news leading to over-pricing. Therefore, even if voluntary disclosure seems to work in most cases these exceptional cases calls for the need for disclosure regulation, at least in the studied area of R\&D (Dedman et al, 2009: 327). In an international setting argumentation for regulating disclosure can also be based on that voluntary disclosure is so unevenly spread. In some countries, like for example the Scandinavian countries, there is a long tradition of voluntary disclosure (Artsberg, Arvidsson, 2007) but in other countries, like for example Ireland (Brennan, 2001) there is little interest from the preparers to disclose voluntarily. Wyatt (2008) points toward the bewildering number of alternative measures and models as deterrent for not having the issue regulated and she would like to have more detail information on separate items than is provided voluntarily.

However, some do not believe that disclosure, either voluntary or mandatory, is the appropriate solution. Luft \& Shields (2001) argue that it does matter whether information about intangibles are disclosed or capitalized. Barth (2003) and Wyatt (2008) claim that disclosure is not an alternative that can substitute for recognition since the two different ways to provide information have different effects on the share prices. 


\section{METHODOLOGY}

With reference to Italian listed companies, this paper aims at answering the following questions: do financial statements provide adequate information about the capitalization of costs related to intangible assets? Is the information provided reliable?

The aim of the paper is to verify if listed companies merely comply with law or provide additional information on cost capitalization. The present research is part of a national project funded by the Italian Minister of University and Research (PRIN, 2009). It adopts a qualitative approach and focuses on 250 Italian listed companies (excluding banks and insurance firms) which have reported intangible assets in the period 2008-2010. The reporting period is derived from the reference to PRIN and uses deductive methodology; empirical- statistic methodology and participatory methodology. Then this paper is, merely, an empirical study, referring to other literature the analysis of managerial accounting system.

The work has been structured in these important steps:

(6) The first step is the identification of companies listed on the Italian Stock Exchange in 2008, 2009 and 2010; the second step is a collection of personal data of the company and information about their objects; defining the scope of research; extraction of quantitative information from the database: AIDA; acquisition of financial statements complete with notes; integration from the output data from AIDA with those contained in the notes.

(7) The second step is defining the scope of search by eliminating: the financial and insurance companies; companies based abroad; companies not on the stock exchange in 2010 and those failed in 2010; the doubles names.

(8) An other important phase is preparation of reports containing the changes in individual items of intangible assets; the definition of thresholds of significance (soglie di significatività); analysis of the notes of the companies with significant changes.

In particular we have performed a document analysis of financial statements (i.e. Notes to the accounts) of those companies recording (in one or more years under investigation) an increase in value of at least 500.000 euro in any given intangible asset (the value increase should also be greater than or equal to $25 \%$ ). Minimum values have been set in order to identify companies with significant assets to disclose where it makes more economic sense to adopt internal control systems and cost accounting to measure intangibles.

The reading of the notes has been a critical step in the search. Consultation of notes was carried out for different reasons:

- Search for causes (purchasing, internal increments);

- Only in the case of internal increases, searching for information on the calculation methods used. 
- Then a relevant step is development of questionnaires sent to companies. More than 100 questionnaires have been sent by e-mail to companies whose intangible assets' growth was related to cost capitalization in order to check for management accounting system application. Questionnaires have been addressed to the Accounting Department, in particular CFOs.

\section{RESULTS}

\section{In the financial statements}

Ingeneralitwaspossibleto detectthefollowingsituationwhichisgivenexperience from reading the following two charts. In particular, the two graphs show the consistency of intangible assets in the subjectcompanies. Thefirst is in reference to thefinancial statements. The second is in reference to the consolidated-financial - statements. Basically, looking to separate financial statements 114 companies show significant changes of intangible items. On the other hand, looking to consolidated financial statements 175 companies show significant changes of intangible assets.

In the financial statements the item that showed the highest variation is represented by: intangible assets in process and advances, followed, soon after, to: concessions, licenses, trademarks and similar rights .

If we look at the consolidated financial statements, however, the first item is given by: concessions, licenses, trademarks and similar rights and was followed soon after by other intangible fixed assets and then intangible assets in process and advances.

Figure 1.: The data processing (in the financial statements)

Start-up and expansion costs

Research, development and advertising costs

Industrial patents and intellectual property rights

Concessions, licences, trademarks and similar rights

Goodwill

Intangible assets in process and advances

Other intangible fixed assets

Total companies that show significant variations

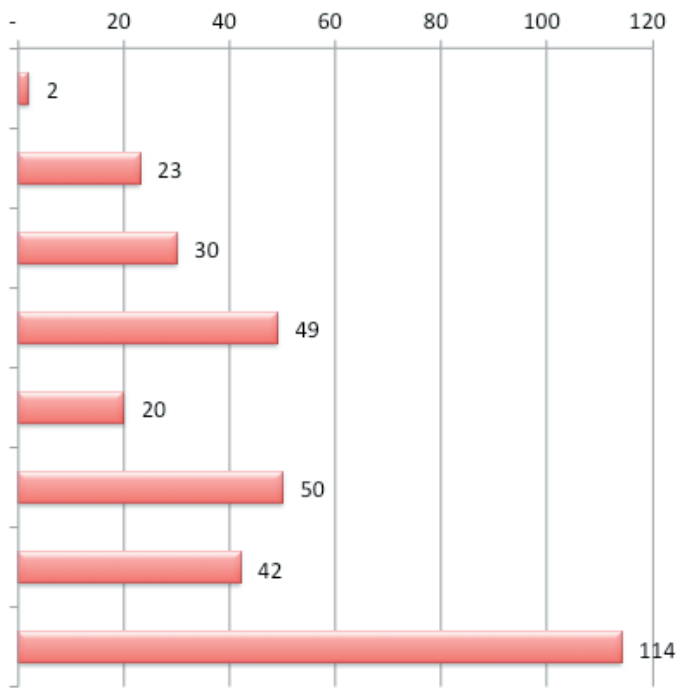


Figure 2.: The data processing (in the consolidated financial statements)

$$
\begin{aligned}
& \text { Start-up and expansion costs } \\
& \text { Research, development and }
\end{aligned}
$$

\section{Goodwill}

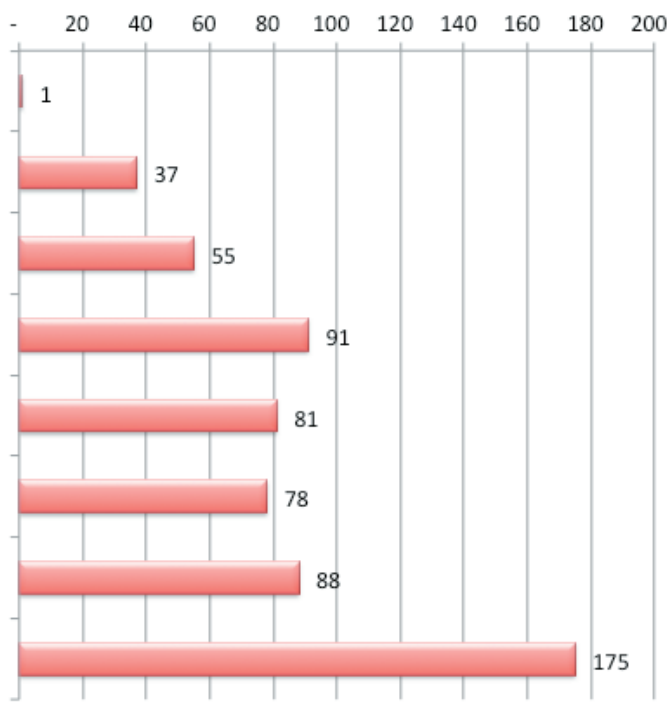

Source: Authors' calculations.

To identify situations in which it is assumed the use of cost accounting systems, we have been studied the absolute and percentage changes of each intangible asset for each year. The following chart shows what has been shown just above.

Figure 3.: The data processing

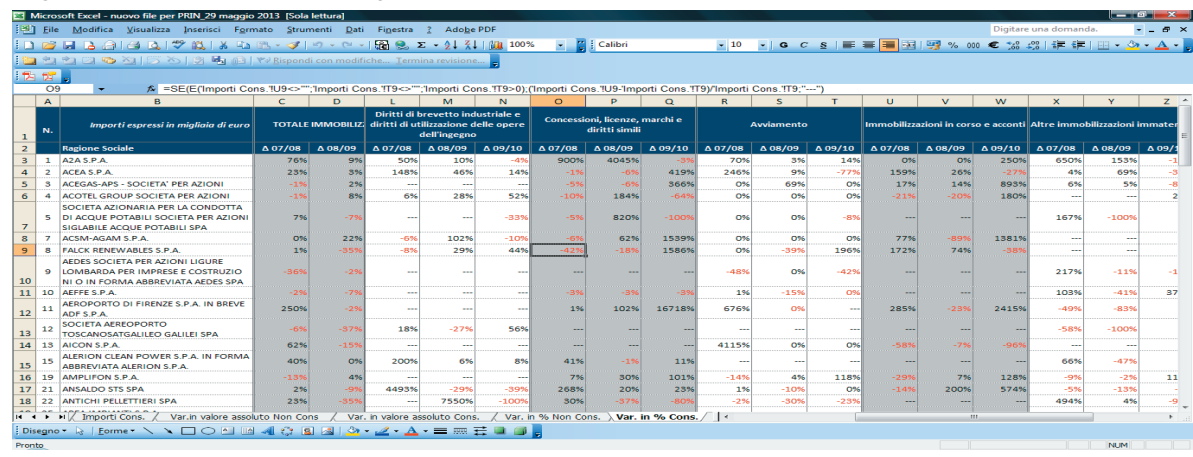

Source: Authors' calculations. 
Table 1.: The following table lists some examples of excerpts of notes of companies with important variations in intangible items

\begin{tabular}{|r|r|r|}
\hline Area "Plants" & $\mathbf{2 0 0 8 - 2 0 0 9}$ & \multicolumn{1}{c|}{ R\&D and Advertising } \\
\hline & Variation $\%$ & $85^{\%}$ \\
& Variation in absolute & $5^{30.000}$ \\
& Absolute value & 1.153 .000 \\
\hline
\end{tabular}

Source: Authors'.

The increase of costs for R \& D is due to four activities / projects of total value of 914,000 (exclusive of depreciation, amortization and the increase amounts of $530,000)$.

Figure 4.: Excerpts of Notes

\begin{tabular}{|c|c|c|c|c|c|c|}
\hline ELR nousand) & $\begin{array}{r}\text { Development } \\
\text { sosts }\end{array}$ & $\begin{array}{r}\text { Patents a } \\
\text { sinilar nigats } \\
\end{array}$ & $\begin{array}{c}\text { Concassions, } \\
\text { licenses and } \\
\text { tracemarks }\end{array}$ & Dther & $\begin{array}{l}\text { Assets under } \\
\text { development }\end{array}$ & Total \\
\hline \multicolumn{7}{|c|}{ N1 Dosember zoco broken-domn os follows } \\
\hline $\cos t$ & 10,324 & 993 & 2,526 & 2,950 & 309 & $17,6,2$ \\
\hline Grats & . & - & (9) & . & . & (9) \\
\hline Amortisaion and imparmert & $(10,324 !$ & $(620)$ & $(1.5 \backsim 1)$ & (2556) & - & (15.,991) \\
\hline Eock value & · & 372 & 926 & 404 & 309 & $2,5 \div 2$ \\
\hline Itretsinte ile & . & 45 & 731 & 10 & 0,515 & 0.8 .0 \\
\hline sales & . & . & . & - & . & . \\
\hline Amortisaion & & $(2 \div 0]$ & (522) & $|244\rangle$ & . & $(976)$ \\
\hline \multicolumn{7}{|c|}{ ¿1 Jecembar 2040 breken-down as follows } \\
\hline Cost & 10,324 & 1,038 & 3,257 & 2,976 & 6,827 & 24,422 \\
\hline Ğa Its & . & . & ;9) & - & - & (9) \\
\hline imortisa,icn and impairmerk. & $1] 4,324$ & (8su; & (21:3) & $(2,800)$ & - & (16,Ner) \\
\hline Dock ralise & . & $20 \mathrm{~A}$ & 1,155 & 170 & 6.827 & a,348 \\
\hline
\end{tabular}

Source: Notes to the Financial Statements at 31 December, Ansaldo (2010).

Intangible assets showed a balance of EUR 8,34,6 thousand compared with EUR 2,512 thousand in 2009 with a net increase od EUR 5,834 , thousand mainly referable to assets under development as described below.

The item "Development costs" relates to the "Stream" project" (Transportation Solutions Business Unit). This category was fully amortised in the previous years.

The item "Patents \& similar rights" (EUR 208 thousand) showed an increase of EUR 45 thousand due to a tool of collection, management and analysis of test data on the web-based platform by the test engineering body (Tito).The item "Concessions, licenses and trademarks" (EUR 1,135 thousand) refers to software licenses; the investments made in the year (EUR 731 thousand) mainly referto the purchase of SAP unlimited licenses through the LULA agreement for EUR 390 thousand, SAP Treasury Platform licenses for EUR 75 thousand, Office Sharepoint (Standard \& Enterprise) licenses for EUR 178 thousand finalised to the creation of a global intranet. The historical cost of this item showed a decrease due to the grants related to the financial facilities in accordance with the 2nd call for PIA Innovazione for an amount of EUR 9 thousand. 
It should be noted that as a result of the said grants, the fixed assets covered by the facility cannot be sold for a period of five years. The historical cost for the concessions, licenses and trademarks subject to this obligation is equal to EUR 21 thousand.

The item "Other" (EUR 176 thousand), attributable to the Transportation Solutions Business Unit, refers primarily to software purchased

from third parties in support of the activities for designing and planning engineering lines and for the development of the internal process of planning, costs control and project management.

The investments for EUR 16 thousand refer to the capitalisations of the costs related to branches.

The item "Assets under development" (EUR 6,827 thousand) showed in the year an increase of EUR 6,018 thousand mainly ascribable to the projects started in the context of the widest reorganisation activities at world level (Fast Forward Driven by Business).

Specifically, the increase is attributable to the following projects:

- Implementation of the Group "New Controlling Model" on the new transitional platform SAP ECC 6.0, started in the course of 2009, for EUR 3,705 thousand;

- Product Data Management (PDM), regarding the implementation of Team Center as the only product data management system, integrated with SAP for EUR 1,678 thousand;

- Life Cycle Management (LCM), relative to the implementation of the new project planning and control model made through SAP /Primavera integration for EUR 451 thousand;

- HCM regarding the implementation of the SABA tool in support of the process to assess the competencies and objectives of resources by the HR department for EUR 174, thousand;

- The remaining portion equal to EUR 10 thousand relates to the implementation of new functionalities for a data collection tool.

\section{In the questionnaire}

The questionnaire was structured to focus on some key issues. In particular we have asked the following questions:

The items: if the increases are related to the capitalization of direct labor costs, materials, or are related to other cases of capitalization; if the quantification of the costs mentioned above was carried out through the use of a system of analytical accounting, cost accounting, or other; if the accounting systems are integrated; alternatively, an indication of how the costs are recognized ( single cards, spreadsheets or other tools ).

Below you can find the questionnaire we used for our analysis. 


\section{A2A s.p.a.}

We have examined the consolidated financial statements for the years 2008 , 2009 and 2010 and with reference to the following items, will be grateful if you provide us with the following information .

Items:

\begin{tabular}{|l|r|r|r|}
\hline \multicolumn{1}{|c|}{ Item } & \multicolumn{1}{|c|}{ year } & \multicolumn{1}{c|}{ Euro } & Notes \\
\hline Patents & 2008 & 7.000 & \\
Concessions & $2008 / 2009$ & $18.000 / 809.000$ & \\
Goodwill & 2008 & 236.000 & \\
Assets under & 2010 & 15.000 & \\
construction & $2008 / 2009$ & $13.000 / 23.000$ & \\
Other & $2008 / 2009$ & $149.000 / 162.000$ & \\
Differed taxes & & \\
\hline
\end{tabular}

Requested information:

1) The increases reported are related to the capitalization of costs of labor, materials and others, or are related to other cases of capitalization ( you can give more than one answer) ?
a) labor;
b) materials and others;
c) other.

2) For quantification of capitalized costs have you used managerial accounting systems / cost accounting/industrial accounting ? yes No

3) If question 2 ) you answered "yes", these systems are integrated into the general ledger accounting system ( that is, the input data feed general ledger accounting and cost accounting at the same time) ?

yes No

4) If question 3 ) you answered " no", the surveys are carried out on the costs :

a) through a system of autonomous accounting ;

b) through cards, spreadsheets and other tools;

c) other.

As seen above, the answer to the questionnaires was, unfortunately, very low. Also essentially, analyzing the results of the questionnaires we have collected emerged the same situation already highlighted by the consultation of Notes. Since the response rate has been very low, respondent companies have been further investigated recurring to direct interviews. 


\section{CONCLUSIONS}

After these results we can try to conclude this paper with some observations.

In the last decades and especially after the 2008 financial crisis, there has been a huge debate about the transparency of companies' financial information (Alexander, Nobes, 2007; André, 2009; Barth, Landsman, 2010; T.J. Linsmeier, 2011). New regulations are constantly being issued, however, academic literature still highlights the scarcity of information regarding intangible assets disclosed in financial statements (Bozzolan et al., 2003; Liao et al., 2013) and the problems of their recognition and measurement (Cañibano et al., 2000; Eckstein, 2004: Sevin et al., 2007). This applies especially to internally created intangibles, whose reliability of measurement presents great difficulties and requires internal measurement metrics (Zéghal, Maaloul, 2011).

International accounting standards set the criteria for recognition and measurement of internally created intangibles (IAS 38) and list some costs that can be included in the calculation of the final value disclosed in the balance sheet (i.e. personnel, training, consultancy and raw materials consumption). These costs refer to all costs directly attributable to creating, producing, and preparing the asset for its intended use. However, no requirements are set with reference to the process of data collection and elaboration, leading to put into question the adequacy of the information structure and the consequent reliability of the information disclosed.

With reference to this paper first insights from document analysis reveal a lack of information on cost calculation of internally generated intangible assets. In general from the companies that report important increases of intangible assets we obtained that these increases are related to the capitalization of direct labor costs, materials, or are related to other cases of capitalization. The quantification of the costs mentioned above was carried out through the use of a system of analytical accounting, cost accounting, or other (i.e. S.A.P.) but in many other cases there are no integrated accounting system and these companies use additional documents like single cards, spreadsheets or other tools.

Companies' disclosure is compliant with international standard requirements while there is almost no additional information on metrics and on the information system(s) used to measure costs and the future economic benefits linked to intangibles. Only in few cases companies provide details on activities and projects whose costs have been capitalized. Voluntary information is mainly qualitative in nature. It regards names and types of research projects (for R\&D) and the description of management tools, software and technical platforms under construction. However, no information is disclosed about the measurement process and methods applied. In particular Figure 4. and Figure 5. show the most detailed Notes that we have analyzed in our work. Most of the companies present a very synthetic description that do not help in understanding the accounting procedures inside. 
However we are sure that disclosure can considered as a solution to the negative consequences of non-recognition of intangibles in financial statements. Under current accounting standards, most of the intangible investments are to be expensed when incurred. "The relative lack of accounting recognition of intangibles investments as assets led several researchers to wonder about the consequences of this inadequate accounting treatment on (1) the value-relevance of financial information, (2) the resource allocation in the capital market, (3) the growth in intangible investments, and (4) the market value of the firm"(Zéghal, Maaloul, 2011). In fact, recent studies show that voluntary disclosure of intangibles information is viewed by managers as a solution to compensate for the loss of relevance of financial information. The incorporation of this different information into equity valuation models, mitigates the omitted variables problem present in most current equity valuation models used by researchers.

Researchers studying the socio-economic consequences have generally agreed that inadequate accounting treatment of internally generated intangibles can lead to a misallocation of resources in the capital market. This problem could, nevertheless, be attenuated through greater disclosure of information about intangibles to investors (Zéghal, Maaoluol, 2011).

When it comes to research on market value, Authors are generally agreed that the inadequate accounting treatment of internally generated intangibles leads to systematic misvaluation of companies. However, there is no consensus as to whether these companies are undervalued or overvalued by investors in the capital market. These systematic misvaluations could, nevertheless, be attenuated through greater disclosure of information about intangibles to investors. Indeed, the recent studies on the subject show that intangibles disclosure can supplement the financial information, and that capital markets reward companies for increased disclosure.

As stated by the Authors the conclusions of the article have several practical implications. First, managers should provide more information about their intangible investments in order to attenuate different negative consequences resulting from their inadequate accounting treatment. Second, accounting standard setters should pursue more sophisticated accounting standards for intangibles. They should also provide more detailed guidance to constituents about useful information disclosures on intangibles which would be a particular benefit to intangible-intensive companies. Third, investors should be seeking greater transparency and more disclosure of information about intangibles.

Indeed, we think that future research could focus on the way in which managers and investors recognize the importance of disclosing information on intangibles. Then it is very important underline that future research should consider the disclosure of information about intangibles from a cost-benefit perspective. Finally, we can not forget that we have examined only the accounting results of intangible items. But these values have not only accounting impacts. All that comes from this statement is out of the aim of this paper and, for this, we refer to other specific studies. 


\section{REFERENCES}

Alexander D. and Nobes C., "Financial Accounting: An International Introduction", (Prentice Hall: 2007)

Amir, E., Lev., "Value relevance of nonfinancial information: The wireless communications industry", Journal of Accounting and Economics, 22, (1996:3-30)

André P., Cazavan-Jeny A., et al, "Fair Value Accounting and the Banking Crisis in 2008: Shooting the Messenger", Accounting in Europe 6.1 (2009): 3-24

Artsberg K. \& Arvidsson, S., "The effect of increasing EU regulation on disclosure practices on intangible assets", working paper, Swedish Network for European Studies in Economic and Business, (2007)

Artsberg K. and N. Mehtiyeva, "A literature review on intangible assets. Critical questions for standard setters", june, first draft, (2010)

Ashton, R.H., "Intellectual capital and value creation: A Review", Journal of Accounting Literature, 24. $(2005): 25^{3-134}$

Baldarelli M.G., "The globalization Phenomenon and the Pressure for Accounting Harmonization", in Baldarelli M.G., Demartini P., L. Mosnja-Skare, International Accounting Standards for SMEs: Empirical evidences from SMEs in a Country in transition and a Developed Country Facing New Challenges, (Department of Economics and Tourism "DR. Mijo Mirkovic': 2007)

Barth M.E. and Landsman W.R., "How did Financial Reporting Contribute to the Financial Crisis?", European Accounting Review 19.3 (2010): 399-423

Barth M.E., Landsman W.R., Lang M.H., "International accounting standards and accounting quality", Journal of accounting research, vol.46, n.3, (2007): 467-498

Black, F., Choosing Accounting Rules, (Accounting Horizons, December 1993)

Blair, M.M., \& Wallman S.M.H., "Unseen wealth: Report of thew Brooking task force on understanding intangible sources of value", (Washington, DC: The Brooking Institution Press, 2000)

Boesso, G., \& Kumar, K., "Drivers of corporate voluntary disclosure. A framework and empirical evidence from Italy and the United States", Accounting, Auditing and Accountability Journal, vol 20, no 2, (2007): $269-296$

Bozzolan S., Favotto F. and Ricceri F., "Italian annual intellectual capital disclosure: An empirical analysis", Journal of Intellectual Capital 4.4 (2003): 543-558

Bromwich, M., "Aspects of the Future in Accounting: The Use of Market Prices and "Fair Values" in Financial Reports", in C. Leuz, D. Pfaff and A. Hopwood (eds), The Economics and Politics of Accounting, Oxford University Press, (2004)

Bruni G. and Campedelli B., "La determinazione, il controllo e la rappresentazione del valore delle risorse immateriali nell'economia dell'impresa", Sinergie 3o (1993: 89-101)

Bullen, H. G., and K. Crook, Revisiting the Concepts, FASB and IASB, May 2005

Cañibano L., Garcia-Ayuso M. and Sánchez P., "Accounting for intangibles: a literature review", Journal of Accounting Literature 19 (2000): 102-130

Capodaglio G. and Vignini S., "Il passaggio agli IAS/IFRS: maggiore trasparenza o politica di bilancio?", in L'impatto dell'adozione degli IAS/IFRS sui bilanci delle imprese italiane quotate, ed. Marchi L. et al. (Franco Angeli, 2012) 
Catturi G., "Distorsioni, interferenze e rumori di fondo nella gestione del segnale informativo contabile", RIREA, marzo-aprile (2001): 109-130

Chalmers K., Clinch G., Godfrey J.M., Wei Z., "Intangible assets, ifrs and analyst", earning forecasts, in accounting and finance, $\operatorname{vol}_{52},(2012): 691^{-}{ }^{2} 21$

Dedman, E., Mouselli, S., Shen, Y., \& Stark, A. “Accounting, intangible asstets, stock market activity, and measurement and disclosure policy ", - views from the UK, Abacus, 45:3, (2009): 312-357

Eckstein C., "The measurement and recognition of intangible assets: then and now", Accounting Forum 28 (2004): $139^{-1} 5^{8}$

Evans, L., G. Gebhardt, M. Hoogendorn, J. Marton, R. Di Pietra, A. Mora, K. Peasnell, F. Thinggard and A. Wagenhofer, "Performance Reporting-the IASB's Proposed Formats of Financial Statements in the Exposure Draft of IAS 1", Accounting in Europe, Vol. 3, (2006)

Francis J., Nanda D. Olsson P., "Voluntary disclosure, earnings quality and cost of capital", Journal of accounting research, vol.46, n.1, (2008): 53-99

Gelb D. , "Intangible Assets and Firms' Disclosures: An Empirical Investigation", Journal of Business \& Accounting, 29 (3) \% (4), (2002): 306-686

Guthrie, J., Petty, R., \& Johanson, U., "Sunrise in knowledge economy. Managing, measuring and reporting intellectual capital", Accounting, Auditing and Accountability Journal, volı4, no4, (2001): 365-382

Heslop, J., "Discussion of 'does measuring intangibles for management purposes improve performance?", A review of the evidence'. Accounting and business research, 38:3, (2008): 273-274

Kaufmann, L., \& Schneider, Y., "Intangibles: A Synthesis of Current Research", Journal of Intellectual Capital, vol. 5, no 3., (2004)

Lev, B., "Intangibles: Management”, Measurement and Reporting. The Brookings Institution Press, (2001)

Lev, B., T. Sougiannis, "The capitalization, amortization and value-relevance of R\&D". Journal of Accounting and Economics, 21, (1999): 107-138

Liao P.C., Ann Ling-Ching Chan and Jia-Lang Seng, "Intellectual capital disclosure and accounting standards", Industrial Management \& Data Systems 113.8 (2013): 1189-1205

Luft, J.L., \& Shields, M.D., "Why does fixation persist? Experimental evidence on the judgement performance effects of expensing intangibles", Accounting Review, vol 76, no 4, (2001): $5^{61-587}$

Mancini D., Quagli M. and Marchi L., Gli "Intangibles" e la comunicazione d'impresa, (Franco Angeli, 2003)

Marchi L. and Potito L., "L'impatto dell'adozione degli IAS/IFRS sui bilanci delle imprese italiane quotate ", (Franco Angeli, 2012)

Mcleay S., "Forum guest editorial”, Abacus, vol.(44), No2, (2008)

Mosnja-Skare, A. Galant, "The quality of notes relating SME revenues and expenditures disclosure: empirical study of croatian financial reporting standards (CFRS) implementation", in Economic Research, special issue, (2013)

Penman, S.H., “Accounting for Intangible Assets: There is Also an income Statement", Abacus, vol.(45), no.3., (2009)

Powell, S., "Accounting for intangible assets: current requirements, key players and future directions", European Accounting Review, December, vol (12), no 4, (2003): 797-811 
Pozza L., "Risorse immateriali e bilancio di esercizio: criteri di rilevazione e categorie logiche", Rivista italiana di ragioneria e di economia aziendale, 100.1-2 (2000): $65^{-7} 6$

Ronen, J., "To Fair Value or Not to Fair Value: A Broader Perspective", Abacus, June (2008)

Schipeer K,. "The introduction of international accounting standards in europe: implications for international convergence", in european accounting review, vol14, n.1, (2005): 101-126

Schipper, K., "The introduction of International Accounting Standards in Europe: implications for international convergence", European Accounting Review, 14 (1), 2005: 101-126

Sellhorn T., Gornik-Tomaszewski S., "Implications of the IAS Regulation for Research into the International Differences in Accounting Systems", in European Accounting Review, vol.15, supplement 3, (2006): 187-217

Sevin S., Schroeder R. and Bhamornsiri S., "Transparent financial disclosure and SFAS No. 142", Managerial Auditing Journal 22.7 (2007): 674-687

Skinner, D., "Accounting for intangibles - a critical review of policy recommendations", Accounting and business research, 38:3, (2008): 191-204)

Thomas, A. L., "The Allocation Problem in Accounting Theory", Studies in Accounting Research No. 3, American Accounting Association, (1969)

Turley S., "Discussion of Ronen", Abacus, vol.44, no2, (2008)

Tweedie, D. P., and G. Whittington, "The Debate on Inflation Accounting", (Cambridge University Press, 1984)

Van der Tas L., "Measuring harmonisation of financial reporting practice", in "Accoounting business research", n.7०, (1988)

Vetoshkina E.Yu., Tukhvatullin R.Sh., "The problem of accounting for the costs incurred after the initial recognition of an intangible asset", in mediterranean journal of social sciences, vol.5, n.24, (2014): 52-55

Vignini S., Semprini L., "Il sistema contabile patrimoniale nelle sue diverse evoluzioni", in Rivista Italiana di Ragioneria e di Economia Aziendale, (2010)

Walker, R. G., and S. Jones, "Measurement: A Way Forward", Abacus, October (2003)

Wang C., "Accounting standards harmonization and financial statement comparability: evidence from transnational information transfer", in journal of accounting research, vol.52, n.4, (2014): 955-992

Whittington G., "The adoption of international accounting standards in the european union", in european accounting review, vol.14, n.1, (2005): 127-153

Whittington, G., "Fair Value and the IASB/FASB Conceptual Framework Project: An Alternative View", Abacus, (June 2008)

Wyatt, A., "What financial and non-financial information on intangibles is value relevant? A Review of the evidence", Accounting and Business Research, vol 38, no 3, (2008): 217-256

Zarowin, P., "Discussion of intangible assets and stock prices in the pre-SEC era", Journal of Accounting Research, vol37, supplement,(1999): 45-51

Zéghal D. and Maaloul A., "The accounting treatment of intangibles - A critical review of the literature", Accounting Forum 35 (2011): 262-2 
